\title{
Formulation and Evaluation of Poly Herbal Anti-Diabetic Tablet Dosage Form
}

\author{
D. Mamatha \\ Gland institute of Pharmaceutical Sciences, Shangri-La, Kothapet (V), Sivampet (M) Near Narsapur, Medak \\ (Dist.)-502110, Telanganastate, India
}

\begin{abstract}
The main aim of the work is to formulate and evaluate poly herbal anti diabetic tablets for medicinal purpose by usingMomordica charantia, Mangifera indica, Carica papaya, Syzygium cumini leaves were collected from the local area, dried, powdered and extracted with ethanol separately and stored for further use. Tablets were prepared after preformulation studies and tablets were evaluated by using Weight variation, Hardness, Friability, Thickness and Disintegration Time. Results: Prepared granules by wet granulation method were performed preformulation studies based on the preformulation studies powder flow properties are good and Weight variation was $\pm 5 \%$, Hardness, Friability are respectively $3.5 \pm 0.43 \mathrm{~kg} / \mathrm{cm} 2,0.58 \pm 0.05 \%$. Thickness was measured as $3 \pm 0.02 \mathrm{~mm}$ and Disintegration time $6 \pm 0.32 \mathrm{~min}$ are good. Discussion and Conclusion: Now a day's Herbal medicines plays major role in the treatment than allopathic medicines because of less toxicity. Momordica charantia, Mangifera indica, Carica papaya, Syzygium cumini ethanolic extracts were used to formulate tablets. Based on the results it is clearly concluded that the prepared formulation of poly herbal antidiabetic tablets and evaluations are good.
\end{abstract}

Key words: poly herbal, Momordica charantia, Mangifera indica, Carica papaya,Syzygium cumini anti diabetic tablet, Disintegration time.

\section{INTRODUCTION}

The traditional knowledge on medicinal plants is by the main basis of bio cultural and ecosystem conservation as well as further Pharmacological, Phytochemical, Toxicological and Ecological studies.[1] Traditional medicinal plants widely used and accounts for around 40\% of all health care delivered.[2]

From the past few years there has been an exponential growth in the field of herbal medicine and these herbs are increasing popularity in all over world because of their natural origin and less side effects.

Herbal medicines have good values in treatment in many countries, scientific investigation of Medicinal plants have been initiated because of their potential.[3] Traditional medicine and ethno botanical information play an important role in scientific research.[4,5] In India indigenous medicines have been used in the treatment of Diabetes mellitus since the time of Charaka and Sushruta (6th century BC).[6]

According to WHO estimations, more than $80 \%$ of the world population depends on traditional medicinal practice for primary health care needs.[7] Over 75\% of the world population is depending on local health practioners and traditional medicines for their primary needs.[8] Traditional ethonobotanical studies have received much attention in recent years due to their wide acceptability and clues for new or lesser - known medicinal plants.[9] A number of reviews have been published in the last three decades on plants pharmacological activities. Very recently, two exhaustive reviews have been published based on the global literature survey on 150 plants and 343 plants in different part of the world.[10-25] 
D. Mamatha, International Journal of Ayurvedic\& Herbal Medicine 7(6) Nov.-Dec. 2017 (2956-2962)

Diabetes mellitus is the common endocrine disorder that affects more than 100 million People worldwide (6\% of the population) and in the next 10 years it may affect about five times more people than it does now.[26,27] In India, the prevalence rate of diabetes is estimated to be 1-15\%.[28-30] The disease was well known to the ancient Indian medical experts. All the renowned classic texts of Ayurveda like Charaka Samhita (1000 B.C.), Sushruta Samhita (600 B.C.) and subsequent works refer to this disease under the term Madhumeha or Ikshumeha.

The main objective of the present study was to focus on the formulation and evaluation of poly herbal anti diabetic tablet by using Momordica charantia, Mangifera indica, Carica papaya, Syzygiumcumini Leaves extracts based on the literatures these plants were selected for the formulation of conventional dosage of herbal tablets used for the treatment of Diabetes mellitus.[31-35]

\section{MATERIALS AND METHODS}

\section{Plant Materials collection and Extraction}

The material leaves Momordica charantia, Mangifera indica, Carica papaya, Syzygium cumini.Used in the present study were collected from the local area, dried, powdered and extracted with ethanol. The powdered plant materials are separately extracted by using Soxhlet extractor with ethanol using as a solvent, collected solvent from Soxhlet extractor dried and the extracts were stored for further use.[36-38]

\section{Excipients used to formulate tablets}

In this formulation Lactose, Starch, Di calcium phosphate, Acacia, Aerosil, Magnesium stearate, Methyl paraben, and Propyl paraben used to compose tablets. Di calcium phosphate and Lactose used as Bulking agents, Acacia and Starch used as granulating agents, Aerosil and Magnesium stearate use for lubrication and Methyl paraben, Propyl paraben used as preservatives.[39-41]

\section{FORMULATION OF POLY HERBAL ANTI DIABETIC TABLETS}

In the present study dried ethanolic extracts of Momordica charantia, Mangifera indica, Carica papaya, Syzygium cumini was formulated into tablet dosage form by wet granulation method. [42]

Formulation has the following composition as depicted in the following Table 1.

Table-1 Composition on formulation ingredients for poly herbal anti diabetic tablets

\begin{tabular}{|c|c|c|}
\hline S.no. & Ingredients & Composition \\
\hline 1 & Mangifera indica & $40 \mathrm{mg}$ \\
\hline 2 & Momordica charantia & $30 \mathrm{mg}$ \\
\hline 3 & Carica papaya & $30 \mathrm{mg}$ \\
\hline 4 & Syzygium cumini & $40 \mathrm{mg}$ \\
\hline 5 & Lactose & $100 \mathrm{mg}$ \\
\hline 6 & Starch & $100 \mathrm{mg}$ \\
\hline 7 & Di Calcium Phosphate & $150 \mathrm{mg}$ \\
\hline 8 & Acacia & $10 \%$ \\
\hline 9 & Aerosil & $5 \mathrm{mg}$ \\
\hline 10 & Magnesium stearate & $5 \mathrm{mg}$ \\
\hline 11 & Methyl paraben & $0.1 \%$ \\
\hline 12 & Propyl paraben & $0.1 \%$ \\
\hline
\end{tabular}


D. Mamatha, International Journal of Ayurvedic\& Herbal Medicine 7(6) Nov.-Dec. 2017 (2956-2962)

\section{Preparation of granules by wet granulation method}

○ Starch was weighed and made into an emulsion along with preservatives and cooked well on a water bath until translucent semisolid mass was formed.

- The Acacia binding solution was prepared by using required quantity of water separately.

- The weighed quantities of excipients were mixed thoroughly with extract, the cooked starch and acacia solution were added slowly till the powder became a damp mass.

- This damp mass was passed through sieve number 16 and dried in an oven at a temperature of $105^{\circ} \mathrm{C}$, until granules were dried properly.

$\circ$ Then the dried granules were passed through sieve number 20 and subjected to lubrication.

- Aerosil and Magnesium stearate were mixed thoroughly and sieved through Sieve number 40 and mixed with the dried granules. Finally the tablets were compressed with $17 \mathrm{~mm}$ punches by using single punch machine. (CM D3-16, S.No- A/1882/94, Cadmac )

\section{EVALUATION [43]}

\section{Preformulation studies}

Preformulation studies were performed before formulating the tablets powders were subjected to following evaluation parameters.

\section{Angle of repose}

Angle of repose was determined by using funnel method;in a funnel the accurately weighed blend was taken. The funnel height was arranged in a manner that the funnel tip just touches the "apex of the heap" or "head of blend". Through the funnel "the drug excipient blend" was allowed to flow freely on to the surface. Table 2 shows the relationship between Angle of Repose and Powder Flow. The diameter of the powder cone and angle of repose were calculated by using the following equation.

$\operatorname{Tan} \theta=\mathrm{h} / \mathrm{r}$

Where $\mathrm{h}=$ height of powder cone formed

$\mathrm{r}=$ radius of the powder cone formed.

Table 2 - Relationship between angle of repose $(\theta)$ and powder flow.

\begin{tabular}{|c|c|}
\hline Angle of $\operatorname{Repose}(\boldsymbol{\theta})$ & Type of Flow \\
\hline 25 & Excellent \\
\hline $25-30$ & Good \\
\hline $30-40$ & Passable \\
\hline$>40$ & Very poor \\
\hline
\end{tabular}

\section{Bulk density}

By pouring the weighed quantity of blend into graduated cylinder and measuring the volume.

$$
\begin{gathered}
\text { Wulk Density = --------------------- } \\
\text { Volume of packing }
\end{gathered}
$$

\section{Tapped bulk density}

A known mass of drug excipient blend was placed in a graduated cylinder. The cylinder was tapped on to a hard surface from the height of $10 \mathrm{~cm}$ at two second interval. Tapping was continued, "Until no further change in volume was noted". 
D. Mamatha, International Journal of Ayurvedic\& Herbal Medicine 7(6) Nov.-Dec. 2017 (2956-2962)

$$
\begin{gathered}
\text { Teight of the powder } \\
\text { Volume of the tapped packing }
\end{gathered}
$$

\section{Compressibility index}

The Compressibility index of the blends was determined by Carr's compressibility index. Table 3 shows grading of powders for their flow properties.

$$
\begin{aligned}
& \text { Tapped bulk density-Loose bulk density } \\
& \text { Compressibility index }(\%)=\text {----------------------------------------- x } 100 \\
& \text { Tapped bulk density }
\end{aligned}
$$

Table 3 - Grading of powders for their flow properties.

\begin{tabular}{|c|c|}
\hline $\begin{array}{c}\text { Consolidation Flow index } \\
\text { (Carr's index) }\end{array}$ & Flow \\
\hline $5-15$ & Excellent \\
\hline $12-16$ & Good \\
\hline $18-21$ & Fair to passable \\
\hline $23-35$ & Poor \\
\hline $33-38$ & Very poor \\
\hline$<40$ & Very very poor \\
\hline
\end{tabular}

\section{Physical evaluation of Tablets}

Tablets were subjected to following evaluation parameters.

\section{Colour and appearance}

For the colour and appearance the tablets were visually examined

\section{Weight variation test}

For variation 20 tablets average weight was determined. Individually each tablet weight was examined. In each case deviation from the average weight was calculated and expressed as percentage. Not more than two of the tablets from the sample size deviate from the average weight by a greater percentage and none of the tablets deviate by more than double that percentage.

\section{Hardness and Friability test}

Hardness test and friability tests were performed for the tablets using calibrated Monsanto hardness tester and Roche friabilitor (4 min at $25 \mathrm{rpm}$ ) tests respectively

\section{Thickness}

By using Vernier calipers was used to evaluate thickness of tablets. Thicknesses were evaluated.

\section{Disintegration test for tablets}

Glass of plastic tube [80-100 mm] long with an internal diameter [28 mm] and external diameter [30-31 $\mathrm{mm}$ ] fitted at the lower end with a disc of rust proof wire gauge. Six tablets were placed in the tube, the tube was raised and lowered in such a manner that the complete up and down movement was repeated [28 to 32] per min. The tablets were disintegrated when no particle remains above the gauge, which readily pass through mesh (10 mesh screen). 
D. Mamatha, International Journal of Ayurvedic\& Herbal Medicine 7(6) Nov.-Dec. 2017 (2956-2962)

\section{RESULTS}

Formulations prepared by wet granulation method were tested for the preformulation studies for potential evaluation to tablet compression. All the evaluated Preformulation parameters are shown in table 4. Based on the preformulation studies powder flow properties are good. Then the process is continued with compression of tablet by wet granulation method, after compression tablets were evaluated by Physical parameters observed were displayed on below table 5 .

The finished tablets colour was Greenish White; Weight variation was $\pm 5 \%$, Hardness, Friability are respectively $3.5 \pm 0.43 \mathrm{~kg} / \mathrm{cm} 2,0.58 \pm 0.05 \%$. Thickness was measured as $3 \pm 0.02 \mathrm{~mm}$ and Disintegration time $6 \pm 0.32 \mathrm{~min}$ are good for stability to consume for human use.

Table 4 - Preformulation parameters for poly herbal anti diabetic tablets

\begin{tabular}{|c|c|c|}
\hline S.NO & Parameter & Results \\
\hline 1 & Angle of Repose & $27.15 \mathrm{C}$ \\
\hline 2 & Bulk density & $0.26 \mathrm{~g} / \mathrm{cm}^{3}$ \\
\hline 3 & Tapped bulk density & $0.33 \mathrm{~g} / \mathrm{cm}^{3}$ \\
\hline 4 & Compressibility index & $23.33 \%$ \\
\hline
\end{tabular}

Table 5 - Physical parameters for poly herbal anti diabetic tablets.

\begin{tabular}{|c|c|c|}
\hline S.NO & Parameter & Results \\
\hline 1 & Colour & Greenish white \\
\hline 2 & Weight variation test & $\pm 5 \%$ \\
\hline 3 & Hardness $\left(\mathrm{kg} / \mathrm{cm}^{2}\right)$ & $3.5 \pm 0.43$ \\
\hline 4 & Friability $(\%)$ & $0.58 \pm 0.05$ \\
\hline 5 & Thickness $(\mathrm{mm})$ & $3 \pm 0.02$ \\
\hline 6 & Disintegration $(\mathrm{min})$ & $6 \pm 0.32$ \\
\hline
\end{tabular}

\section{DISCUSSION AND CONCLUSION}

Herbs plays major role in the treatment than the allopathic medicines because of less side effects, low cost and easy availability. The research work done on that basis and the selected plants for the formulation was literally proved for the therapeutic use of antidiabetic purpose.

All the four plants used in the work was Momordica charantia, Mangifera indica, Carica papaya,Syzygium cumini leaves was extracted by using ethanol and the extracts were used to formulate tablets

Tablet and evaluated for physical parameters and standardize as per pharmacopoeia standards. Preformulation study and Physical Parameter revealed that all the values were within acceptable limit. The polyherbal formulation showed significant antidiabetic activity and the tablet standardize as per Pharmacopoeia standards.

Based on results it is concluded that the formulation and evaluations are good. Moreover, further study is required for pharmacological evaluation for the treatment of diabetes mellitus.

\section{REFFERENCES}

1. Habibullah Khan $\mathbf{M}$ and Yadava PS. Antidiabetic plants used in Thobal district of Manipur, Northeast India, Indian journal of traditional knowledge, 2002; 9(3): 510-514.

2. Anonymous, traditional medicine strategy. WHO, 2002-2005; WHO/EDM/TRM/2002.1.

3. Patrick OE. Herbal medicines: challenges. Tropical J Pharmaceutics Res, 2005; 1(2): 53-54. 


\section{Mamatha, International Journal of Ayurvedic\& Herbal Medicine 7(6) Nov.-Dec. 2017 (2956-2962)}

4. Awadh A, Ali N, Al-rahwi IK and Lindequist U. Some medicinal plants used in Yemeni herbal to treat malaria. Afr J Traditional complement Alt Med., 2004; 1: 72-76.

5. Kala CP. Ethno medicinal botany of the Apatani in the Eastern Himalayan region of India. J Ethnobiol Ethnomed, 2005; 1(11): 1-8.

6. Grover JK and Vats V. Shifting Paradigm from conventional to alternate medicine. An introduction on traditional Indian medicine, Asia Pacific Biotechnology News, 2001

7. Malik JK, Thacker AM and Ahmed A. Ethnoveterinary medicine in western India, Ethnoveterinary Research and Development, Edited by Mc Corkle C, (Intermediate Technology Publication, UK), $1996 ; 148$.

8. Kattamani KN, Munikrishnappa MP, Husain SA and Reddy PN. Use of plants as medicine under semi-arid tropical climate of Raichur district of North Karnataka, J Med Aromat Pl Sci, 2000; 22-23: 406-410.

9. Tripathi YC. Ethno medical treasure of tribal Rajasthan, J Non Timbet Forest Product, 2000; 7(1/2): 77-84.

10. Mukherjee SK and Mukherjee S. Therapeutic advances in Diabetes mellitus through ages. J Res Indian Med., 1966; 1-0: 9.

11. Mehta KC. Indian herbal drugs in the treatment of diabetes. Current Med Pract. 1982; 26(10): 305.

12. Aiman R. Recent research on indigenous antidiabetic medicinal plants an overall

13. Assessment. Indian J Physiol \& Pharmacol, 1970; 14(2): 65.

14. Chaudhury RR and Vohora SB. Plants with possible hypoglycemic activity in advances in Research in Indian Medicine Udupa KN, Chaturvedi GN and Tripathi SN (Eds) Banaras Hindu University, Varanasi (India), 1970; 57.

15. Karnick CR. Some aspects of crude Indian drugs plants used in Ayurvedic system of medicine (Madhumeha) (Dia betes). Acta Phytother Amst., 1972; 19: 141.

16. Satyavati GV, Raina MK and Sharma M. Medicinal Plants of India, Indian Council of Medical Research, 1976; 1.

17. Mukherjee SK. Indigenous drugs in Diabetes mellitus. J Diabetic Asso India, 1981

18. Nagarajan S, Jain HC and Aulakh GS. Indigenous plants used in the control of Diabetes in Cultivation and Utilization of Medicinal Plants. Jammu regional research laboratory, 1982; 584-604.

19. Satyavati GV. Pharmacology of medicinal plants and other natural products in Current Research in Pharmacology in India (1975-1982), Das PK and Dhawan BN (Eds), Indian National Science Academy New Delhi, 1984; 119-146.

20. Patnaik GK and Dhawan BN. Pharmacological studies on Indian Medicinal plants in Current Research on Medicinal Plants in India. Dhawan BN (Ed) Indian National Science Academy New Delhi, 1986; 45.

21. Das PK, Dasgupta G and Mishra AK. Clinical studies on Medicinal Plants of India in Current Research of Medicinal Plants in India. Dhawan BN (Ed), INSA New Delhi, 1986; 72.

22. Satyavati GV, Gupta AK and Tandon N. Medicinal Plants of India, Indian Council of Medical Research New Delhi, 1987; 2.

23. Sever BO. Oral hypoglycemic plants in West Africa. J Ethnopharmacol, 1980; 2: 109.

24. Handa SS, Chawla AS and Maninder. Hypoglycemic plants - A review. Fitoterapia 1989; 60(3): 195.

25. Atta-ur-Rahman and Khurshid Zaman. Medicinal plants with hypoglycemic activity. J Ethnopharmacol, 1989; 26(2): 1.

26. Singhal PC and Joshi LD. Role of gum arabica and gum catechu in glycaemia and cholesterolemia. Curr Sci., 1984; 53: 91.

27. WHO/Acadia, Rapport de la Journal International de, diabetes 1992; 14 October. 
D. Mamatha, International Journal of Ayurvedic\& Herbal Medicine 7(6) Nov.-Dec. 2017 (2956-2962)

28. ADA. Clinical practice recommendation 1997, Screening for diabetes. Diabetes care, 1997; 20(1): 22-24.

29. Patel M, Jamrozik K, Allen O, Martin FI, Eng J and Dean B. A high prevalence of diabetes in a rural village in Papua New Guinea. Diabetes Research and Clinical Practice, 1986; 2(2): 97-103.

30. Verma NP, Mehta SP, Madhu S, Mather, HM and Keen H. Prevalence of known diabetes in an urban Indian environment: the Darya Ganj diabetes survey. British Medical Journal, 1986; 293(6544): 423424.

31. Rao PV, Ushabala P, Seshiah V, Ahuja MM and Mather HM. The Eluru survey: prevalence of known diabetes in a rural Indian population. Diabetes Research and Clinical Practice, 1989; 7(1): 2931

32. Patel DK, Prasad SK, Kumar R and Hemalatha S. An overview on antidiabetic medicinal plants having insulin mimetic property. Asian Pacific Journal of Tropical Biomedicine, 2012; 320-330.

33. Rawat Mukesh and Parmar Namita. American-Eurasian J Agric \& Environ Sci., 2013; 13(1): 81-94.

34. Aswini Kumar D and Sudurshan M. Review of flora of anti-diabetic plants of puducherryut. International Journal of Applied Biology and Pharmaceutical Technology, 2011; 2(4): 455-462.

35. Ayesha N, Vinay SB and Vijayalakshmi MA. Current update on anti-diabetic biomolecules from key traditional Indian medicinal plants. Current science, 2013; 104(6):

36. Abdel NS, Fadia SY and Mohamed LA. Medicinal Plants with Potential Antidiabetic Activity and their Assessment. Med Aromat Plants, 2014; 3(1): 1-12.

37. Rangari VD. Pharmacognosy and Phytochemistry, Nasik: Career Publications, 2002; 1st ed: 353 367.

38. Trease GE and Evans WC. Pharmacognosy. London: environmental and. Land-based science, 1997; 14th ed: 340-408.

39. Bruneton. Pharmacognosy and Phytochemistry Medicinal Plants. London: Intercept Ltd, 1999; 2nd ed: $310-354$.

40. Agarwal SS and Paridhavi M. Herbal drug technology. Hyderabad: University Press Private Limited, 2007; 663-671.

41. Jain NK and Sharma SN. A Textbook of Professional Pharmacy. New Delhi: Vallabh Prakashan, 1998; 4th ed: 83-89.

42. Cooper and Gunn. In: Tutorial Pharmacy, JB Publisher New Delhi 259.

43. Harpreet S, Sudhanshu A, Munish M, Kamal KM and Phool C. Development of multicomponent formulation of herbal drugs for evaluation of Antidiabetic activity. Der Pharmacia Letter, 2014; 6(1): 219-223.

44. Lechmann L, Lieberman HA and Kanig JL. The theory and Practice of Industrial Pharmacy Tablets, Varghese publishing house Bombay, $19914^{\text {th }}$ edition 293-345. 